\title{
THE DISTRIBUTION OF WEALTH IN URBAN CHINA AND IN CHINA AS A WHOLE IN 1995
}

\author{
BY BJÖRN GUSTAFSSON* \\ University of Göteborg and Institute for the Study of Labor (IZA), Bonn \\ LI SHI \\ Beijing Normal University and Institute for the Study of Labor (IZA), Bonn \\ AND \\ WEI ZHONG \\ Institute of Economics, Chinese Academy of Social Sciences, Beijing
}

\begin{abstract}
The composition, inequality and determinants of wealth among households in urban China in 1995 are studied. In addition, we compare the wealth distribution in urban China with the wealth distribution in rural China and present the first estimates of inequality in the distribution of household wealth in China as a whole. The results show that housing wealth makes up a large part of net worth in urban China. Most urban Chinese households keep a bank account; debts are unusual. A household's net worth is strongly related to its income and location. Net worth is more unequally distributed among urban households than among rural households. However, compared to the situation in most industrialized countries, net worth in urban China and in China as a whole appear to be rather equally distributed.
\end{abstract}

\section{INTRODUCTION}

Private property played a much more limited role in Soviet-type economies than in industrialized market economies for several reasons. Large enterprises as well as most middle-sized establishments were state- or collectively-owned and the self-employment sector was small. Private persons were not entitled to buy and sell land and private use of land was typically restricted to small areas (the private plot). In urban regions most households lived in state- or collectively-owned housing and there were few owners of private homes or apartment houses.

Economic transformation toward a market economy has changed these circumstances as private property rights have been (re)established. This process has moved at different speeds in different transition countries. In some countries, income fell rapidly for many households during the initial phase of transition, forcing households to decumulate assets, while the opposite case was true for others. Though experiences vary it can be hypothesized that transformation has resulted in private wealth now playing a role more similar to the role it plays in present day industrialized market economies. This means wealth will be fairly unequally distributed; more unequally distributed than income.

Note: An earlier version of this paper was presented at the 21st Arne Ryde Symposium on Non-human Wealth and Capital Accumulation, Lund. We thank the referees of this journal as well as others who have commented on earlier versions.

*Correspondence to: Björn Gustafsson, Department of Social Work, University of Göteborg, P.O. Box 720, SE 40530 Göteborg, Sweden (Bjorn.Gustafsson@socwork.gu.se).

(C) 2006 The Authors

Journal compilation (C) 2006 International Association for Research in Income and Wealth Published by Blackwell Publishing, 9600 Garsington Road, Oxford OX4 2DQ, UK and 350 Main St, Malden, MA, 02148, USA. 
There is limited research on household wealth and its distribution in countries in transition. Our contribution to the literature aims to shed light on the situation in the largest country in transition-China. As is well known, the Chinese strategy of reform has been gradual and the economy has grown rapidly. The first reforms in China were introduced in the rural areas at the end of the 1970s when the household responsibility system was established. It meant that user rights of land were distributed to the peasants, although land could not be sold. The formula applied meant that in many locations land was distributed fairly equally.

Through the work of Terry McKinley, we know that the distribution of net worth among households in rural China was quite equal a decade after the introduction of reform. ${ }^{1}$ According to this study based on data covering a large part of the country for 1988, the user's right to land (which made up almost 60 percent of net worth) was relatively evenly distributed. Roughly 30 percent of average net worth came from private housing which was relatively unevenly distributed. Financial assets were on average unimportant. The Gini coefficient for net worth in rural China was found to be 0.31 . This is very low by international standards.

It is also known that as the reform process has progressed and the economy has grown, household wealth in rural China has increased rapidly. Brenner (2001), working with similar though more recent data than McKinley, reports a real growth in average total wealth of rural households from 1988 to 1995 amounting to 4.4 percent per annum. Although all components of wealth had increased, changes in average values were small for user rights of land (1.8 percent per annum), but very large for gross financial assets (27.0 percent per annum). The Gini coefficient for wealth in rural China had increased to 0.35 , thus clearly indicating a change towards less equality. Still, the distribution of household wealth in rural China was remarkably equal; more equal than the distribution of annual income.

What has happened with private wealth and its distribution in urban China? As the economy has grown, many households have had the opportunity to accumulate financial assets and buy consumer durables. As economic growth has been spatially unbalanced, households living in some locations can be supposed to have become wealthier than households living in others. In addition, there have been changes in property rights to housing. Previously, most urban residents lived in low-rent apartments owned by their work unit or by the local government. Today the picture has changed due to housing reform which has moved forward at different rates in diverse areas of urban China. It has led to a considerable proportion of urban dwellings being privatized. Often the former tenants were given the opportunity to buy their apartments at a price lower than on the emerging private market. While rents for remaining public housing have increased, they are still lower than on the emerging market.

${ }^{1}$ See McKinley (1996), which is based on McKinley (1992). Shorter versions of single chapters in McKinley (1996) have also been published as articles, e.g. McKinley (1993). In her study, net worth had the following main categories: land, fixed productive assets, net worth in housing as well as gross financial assets. From this non-housing debts were subtracted. 
Despite a population of 300 million, the urban Chinese population's wealth situation has attracted very little attention among researchers until now. ${ }^{2}$ We have found no previous assessment of inequality in total wealth or the importance of various components for inequality of wealth. No one has previously compared urban and rural China regarding household wealth. As a consequence of the lack of assessments of the wealth situation in urban China, there are no previous assessments of wealth and its inequality in China as a whole. The purpose of this paper is to address this shortcoming. The analysis is based on the 1995 Urban Household Income Survey which covers cities and towns of various sizes located in 11 provinces.

Our main findings are the following. The largest wealth component for urban households in China is housing. Most urban Chinese households keep a bank account; debts are unusual. A household's net worth is strongly related to its income and location. Inequality in the distribution of net worth is greater in urban China than in rural China. However, compared to the developed market economies, the distribution of wealth in urban China and in China as a whole appears rather equal.

The paper is arranged in the following way: In the next section the context, data, and the definitions of wealth and its components are presented. Findings on total wealth and its components are reported in Section 3. In Section 4 we report results on inequality in net worth in urban China and results from a wealth function analysis are reported in Section 5. The comparison with results for rural China is made in Section 6 where we also report estimates for China as a whole. Finally, we summarize the findings in Section 7.

\section{Context, Measurement and Definitions}

We use data from the Urban Household Income Survey conducted in 1996 by the Institute of Economics, Chinese Academy of Social Sciences for the reference period of $1995 .^{3}$ The data sets were derived from larger samples drawn by the National Bureau of Statistics (NBS). Once selected as a member of such a sample, a household is visited monthly by an enumerator for a period of three years after which the household is dropped from the sample. The method NBS uses for selecting households is designated a "two-stage stratified systematic random

\footnotetext{
${ }^{2}$ We are aware of only two exceptions. One is Pudney (1993) who studied life-cycle effects of age on income as well as on wealth for samples of urban and rural Chinese households collected in 1987. His results indicate that very little of observed inequality can be explained by life-cycle factors. The other is a study of the largest component of urban wealth - housing - based on data from the two cities of Tianjin and Shanghai in 1993 by Logan et al. (1999). These authors relate housing size and housing facilities to a number of characteristics and report for example that both variables are strongly related to income of the household.

${ }^{3}$ The questionnaires are reproduced in Zhao et al. (1999). In 1995 the growth rate was 10.5 percent, close to the average growth rate of the 1990s, and the price index of consumer goods was up by 17 percent. It is not known to what extent there were changes in housing prices as there was no housing price index at that time. However, the price index of building materials does not show a sharp rise in 1995 (6.4 percent, see p. 312 in China Statistical Yearbook 2002). It is therefore hard to know if the value of housing and thus the picture of the distribution of wealth would have been much different if the survey had been conducted another year.
} 
sampling scheme." All households with a hukou (register permit) should have had the same probability of entering the sample.

The Urban Household Income Survey covers eleven provinces where 49 percent of China's urban population lives. Respondents were chosen from the NBS samples in order to obtain information on conditions in various regions of China and of cities and towns of various sizes. The following provinces were surveyed: Anhui, Beijing, Gansu, Guangdong, Henan, Hubei, Jiangsu, Liaoning, Sichuan, Shanxi and Yunnan. There was very little non-response. The survey data include 6,935 households and 21,696 individuals.

It should be noted that the rural-urban migrants without an urban hukou were not covered by the survey, implying that the figure of wealth inequality presented in this paper is probably an underestimation at least for urban areas; rural migrant households most likely possess less wealth than their urban counterparts. ${ }^{5}$ Also, possible failures by respondents to report financial assets at their full market values (a phenomenon not limited to urban China), leads most probably to underestimation of inequality in the distribution of wealth. However, as reported in the next section, nearly 90 percent of the households reported positive financial assets.

While the survey was conducted by China's National Bureau of Statistics by request of the Institute of Economics, Chinese Academy of Social Sciences, the questionnaire was designed by the members of a project team consisting of Chinese and international scholars. In addition to detailed questions related to income and income components attributable to households or individuals, a number of questions were also asked about possession of wealth and its components (such as financial assets and debts) to households in the sample. For example, respondents from each household were asked to evaluate durable goods at market prices.

Housing is a significant part of household wealth in many countries and China is no exception. Housing in China can be privately owned (which is typically the case in rural China), owned by a work unit or by the municipality. After 1949, the share of private housing in urban China decreased steadily for several decades and was relatively small when China began its transition. Work unit housing is owned, managed and distributed by work units for their employees as an employment benefit. Work units also play a role in municipal housing, which is housing managed by the municipal housing office regardless of who built or owns it. For people living in private housing, we simply use the market price as reported by the respondents in our sample. However, for households living in public housing the situation is more complicated, which we will now discuss.

${ }^{4}$ This method is briefly explained in China Statistical Yearbook 2004, pp. 352-54.

${ }^{5}$ Data on the scale of rural to urban migration in China is incomplete but the general perception is that the flows are large, and that Chinese cities have considerably larger populations than what is indicated by official figures that are only based on dwellers with resident permits. Most recent migrants are young adults looking for manual jobs, many with short educations. Empirical studies on the migrant's economic situation in the Chinese urban environment are relatively few. One exception is found in Meng (2000) and refers to samples for Shanghai taken in the mid 1990s. According to this, migrant workers on average earned only 56-64 percent as much as urban residents. Given a positive relation between earnings and household wealth in our data, we expect average net worth of rural migrants to be lower than among urban residents. Most probably we underestimate the true inequality in household wealth. Admittedly, serious this shortcoming of not considering rural migrants is shared by all previous studies of urban income inequality and poverty in China. In our opinion collecting household data on rural to urban migrants should have top priority for China. 
At the level of work unit, the allocation of housing is administrative. Factors typically affecting the allocation include occupational rank, years of work experience or seniority, employment of both husband and wife at the same work unit, family size and demographic characteristics of household members. These criteria can be generalized as economic contributions, merits and housing needs (see $\mathrm{Wu}$, 1996). This institutional arrangement for the allocation of public housing implies a relatively equal housing distribution among urban households.

However, a heavy financial burden on the government, the "locking in" of workers to a particular work unit, and poor housing conditions led to a decision for housing reform in urban China. The process has been gradual. (Wang and Murie, 2000; Zhang, 2000; Zhu, 2000) Housing reform has many elements; one important component has been to encourage current tenants to buy their apartments. As a consequence, results from a large survey show that in 1996, the proportion of households owning homes is as large as the proportion renting (Huang and Clark, 2002). ${ }^{6}$ This study also shows that home-ownership varies widely by location, indicating that housing reform had proceeded at different speeds at different locations.

According to the objective of the housing reform initiated by the central government, all existing public housing is to be sold to the tenants sooner or later. Historical experience shows that tenants typically have been allowed to buy their current housing at a price considerably lower than the prevailing price in the housing market. For such households, a significant capital gain was realized when purchasing public housing. As a result, wealth distribution in urban China became unequal in the early stages of housing reform since housing privatization was implemented for only a small proportion of all urban households.

Using the information from the questionnaires, we are able to estimate the level and distribution of average net worth and its components. In the analysis we distinguish between some broad types of assets. As discussed above, housing assets consist of the market value of private housing. Financial assets can be divided into a number of different components: (1) term deposits; (2) current account deposits; (3) stock shares; (4) bonds; and (5) other financial assets. The definition of wealth also includes production assets used in private business activities. ${ }^{7}$ In addition, the responding households were asked to specify debts, if any, and the questionnaire differentiated between different types of debt. Net worth is hence the difference between total wealth and debts. The questions in the survey thus should allow many types of assets to be captured, resulting in the concept of wealth covered here to be relatively broad. However, the concept of wealth does not cover the value of future income streams due to pension rights, for example.

${ }^{6}$ The proportion of renters is somewhat higher than in our sample, which could be due to the survey by Huang and Clark (2002) having been conducted one year later. Our data shows that 30 percent of the households had bought their housing through the housing reform and 11 percent lived in housing they had built themselves or inherited. In addition, about 55 percent of urban households lived in rented public apartments.

${ }^{7}$ It should be remembered that we work with a sample survey which does not include a subsample of very wealthy households. Thus we are not able to give precise estimates of assets owned by the few very rich households in China, e.g. fixed assets located abroad. 
TABLE 1

Composition and Mean Value of Household Wealth in Urban China in 1995

\begin{tabular}{lccc}
\hline \hline & $\begin{array}{c}\text { Proportion with } \\
\text { Value }>0\end{array}$ & Mean (yuan) & $\begin{array}{c}\text { Proportion of Net } \\
\text { Worth (\%) }\end{array}$ \\
\hline Housing & 41.6 & $17,807.4$ & 44.8 \\
Financial assets & 87.6 & $11,390.2$ & 28.6 \\
Durable goods & 99.4 & $9,076.5$ & 22.7 \\
Production assets & 2.5 & 464.8 & 1.2 \\
Other assets & 39.3 & $1,699.3$ & 4.3 \\
Gross wealth & 100.0 & $40,438.3$ & 101.5 \\
$\quad$ Debts & 11.2 & 810.8 & 1.5 \\
Net worth & 99.0 & $39,627.5$ & 100.0 \\
\hline
\end{tabular}

Source: Urban Household Income Survey 1995 by Institute of Economics, CASS.

\section{Total Wealth and its Components}

In Table 1 we report mean values as well as the proportion of households with a positive value for the various wealth components for urban China in 1995. We also report the estimates of gross wealth and net worth. Housing is by far the most important wealth component, even though more than half of the households in our sample live in public housing. The average value for housing wealth according to our estimation is about 18,000 yuan. This number does not appear high when converted to US\$ using the prevailing exchange rate. However, it is about three times as large as the annual money wage of an urban worker.

An overwhelming number of households also have positive values for financial assets and durable goods. The average sizes of these two components do not differ much from each other; the financial assets on average amount to 11,400 yuan, a figure somewhat larger than the figure for durable goods which amounts to about 9,100 yuan. Both numbers are larger than the monetary annual wage for an urban worker.

Looking in detail at the financial assets (Table 2), we find term deposit accounts to be most important by far, making up three-fifths of the average value of financial assets. Bonds are relatively widespread among urban households as about two out of five households reported possession of this asset. Only a small minority (4 percent) of the households reported possession of productive assets. The Chinese stock market is new. In December 1990 the Shanghai Stock Exchange was inaugurated and the Shenzhen Stock Exchange began in April 1991. Since then, possession of stocks has spread rapidly. According to Table 2, as much as 9 percent of Chinese urban households were stockholders in $1995 .{ }^{8}$ Stocks stood for 3 percent of all financial assets in 1995, a proportion similar to the component for money lent out.

Turning to debts, we find them to be rather unusual, as only 11 percent of the households reported any debts at all. The average amount of debts computed for all households was only about 800 yuan. The most usual type of debt was housing

${ }^{8}$ Stock shares consist of two types. One is exchangeable on the stock market. The other type comprises shares issued by work units, which are not allowed to be traded within a fixed period. However, these two types of stock shares were not differentiated in the questionnaires. 
TABLE 2

Composition and Mean Value of Financial Assets and Debts

\begin{tabular}{lccr}
\hline \hline & Proportion with Value $>0$ & Mean (yuan) & Percentage \\
\hline Financial assets & 87.6 & $11,390.2$ & 100.0 \\
Of which: & 72.3 & & \\
Term deposits & 53.5 & $7,108.1$ & 62.4 \\
Current deposits & 8.7 & $1,225.7$ & 10.8 \\
Stocks & 39.1 & 392.7 & 3.5 \\
Bonds & 9.9 & 990.5 & 8.7 \\
Money lent out & 3.7 & 327.0 & 2.9 \\
Production funds & 9.1 & 171.4 & 1.5 \\
Investments (excluding bonds & & 519.0 & 4.6 \\
and stocks) & 6.8 & 655.8 & 5.8 \\
Other financial assets & 11.2 & 810.8 & 100.0 \\
Total debts & & & 74.5 \\
Of which: & 7.2 & 603.9 & 9.5 \\
Housing debts & 0.6 & 76.7 & 3.3 \\
Business debts & 0.9 & 26.9 & 3.4 \\
Durable purchasing debts & 1.4 & 27.8 & 5.2 \\
Medical care debts & 1.9 & 42.1 & 4.1 \\
Hardship debts & 1.0 & 33.4 & \\
Other debts & & & \\
\hline
\end{tabular}

Source: Urban Household Income Survey 1995 by Institute of Economics, CASS.

debt. The small degree of indebtedness means that on average net worth is very similar to gross wealth and amounts to 39,600 yuan.

\section{Inequality in Net Worth in Urban China}

To investigate the inequality of wealth quantitatively, we use two measures: the Gini coefficient and the concentration coefficient. We measure inequality in total net worth by the Gini coefficient. This in turn can be decomposed as the weighted sum of concentration coefficients for the various wealth components, as originally proposed by Rao (1969) and fully deliberated by Pyatt et al. (1980). The weights are the relative shares of wealth components in total net worth, which thus add up to 1 . Therefore, the relationship between the two measures can be expressed as follows:

$$
G=\sum_{k} \frac{\mu_{k}}{\mu} C_{k}
$$

where $G$ is the Gini coefficient, $\mu_{k}$ and $\mu$ are the means of wealth component $k$ and total net worth, and $C_{k}$ is the concentration coefficient of wealth component $k .{ }^{9}$ The concentration coefficient reflects the association between wealth component $k$ and net worth. It can assume values ranging from -1 to +1 . If the concentration

${ }^{9}$ The concentration coefficient is defined similarly to the Gini coefficient. However, while the Gini coefficient is defined based on the Lorenz curve, the concentration coefficient is based on the concentration curve; that is, the households are ranked according to the size of their net-worth. See for example Lambert (2001, p. 40). 
TABLE 3

The Distribution of Household Wealth in Urban China in 1995

\begin{tabular}{lcccc}
\hline \hline & Proportion of Net Worth & Gini & Concentration Coefficient & Contribution \\
\hline Net worth & 100.0 & 49.6 & & 100.0 \\
Housing & 44.8 & 77.4 & 69.2 & 62.5 \\
Financial assets & 28.6 & 59.7 & 40.8 & 23.6 \\
Durable goods & 22.7 & 37.8 & 20.1 & 9.2 \\
Production assets & 1.2 & 99.2 & 76.5 & 1.8 \\
Other assets & 4.3 & 82.1 & 39.3 & 3.4 \\
Debts & -1.6 & 95.3 & 13.9 & -0.4
\end{tabular}

Source: Urban Household Income Survey 1995 by Institute of Economics, CASS.

coefficient of a wealth component is greater (or smaller) than the Gini coefficient of total net worth, this wealth component would be regarded as being disequalizing (or equalizing). When the wealth component has a concentration coefficient equal to the value of the Gini coefficient of net worth, it implies that the distribution of the wealth component is as equal as net worth.

The relative contribution of a wealth component $k$ to inequality of net worth (E) can be expressed as:

$$
E=\frac{u_{k} c_{k}}{G}
$$

where $u_{k}$ is share of wealth component $k$ in net worth (that is, the mean of wealth component $k$ in relation to total net worth).

Table 3 shows both the Gini coefficients and concentration coefficients for the various wealth components as well as the Gini coefficient for net worth. The Gini coefficient for net worth is 49.6. This is higher than income inequality in urban China in the same year. Using the same survey Gustafsson and Li (2001) report a Gini coefficient of 27.6 percent for equivalent income using individuals as the unit of analysis.

Table 3 shows that the Gini coefficients for some of the wealth components are rather high, reflecting that a considerable proportion of the households possess no such assets. Housing assets have a high concentration coefficient. Not surprisingly, the concentration coefficient for durable goods is considerably lower than the Gini coefficient for net worth. Thus while wealthier households have more durables than other households, the contribution of durables to inequality in net worth is smaller than its proportion of total wealth. Debts also have a relatively small concentration coefficient. The highest concentration coefficient is reported for production assets.

\section{Determinants of Household Wealth}

In this section we address the issue of what affects the amount of wealth a household possesses in urban China. We estimate wealth functions using OLS. Explanatory variables indicate a household's position in the life cycle, its size and socioeconomic circumstances such as education, occupation, gender and member- 
ship in the Communist Party. We also include dummies for province and household income, the latter is entered in the second specification reported in Table 4. The dependent variable is net worth. In a sensitivity analysis we estimated the same specification using the logarithm of net worth as dependent variable, and in the text we concentrate on results that are robust with regard to the dependent variable.

Several findings stand out in Table 4. Age of the household head matters. If the head is aged 51-60 net worth is higher than if the head is older. This result is reasonable, as older persons have had little opportunity to save for retirement in a rapidly growing economy. ${ }^{10}$ Household net worth increases by number of household members, but in the second specification is the t-statistics low. Turning to socioeconomic variables we find that if the head of the household is a head of an enterprise, net worth is higher according to both specifications. This might reflect better opportunities to accumulate. ${ }^{11}$ Effects of the household head being male and household head being a member of the Communist Party are relatively small and estimated with low t-statistics in both specifications. There is little evidence for education of household head having an effect on net worth once household income is included in the specification. The only exception is if the head has low education, but in an alternative specification with the logarithm of net wealth as the dependent variable the t-statistics is low.

The main findings for the wealth function analysis show that location (as measured by province), as well as income of the household have rather large effects on household net worth per capita; households in prosperous provinces are rich as are high income households. This situation is evident when we predict net worth per capita for a household with given characteristics but located in different positions of the income distribution and at various stages of the life cycle. We make predictions for households living in the north-eastern province of Liaoning and the south-eastern province of Guangdong. These provinces were polar opposites regarding economic growth at the time our survey was conducted. Liaoining, although industrialized early, has been relatively stagnant and has experienced serious unemployment. In contrast, Guangdong has become the leader of economic growth due to an early "opening up" and massive foreign investments.

The predictions reported in Table 5 are made for a three-person household with a male skilled worker as head who is not a party member and who has an upper-middle school education. The upper third of the table shows the situation if the household belongs to the second lowest decile of the income distribution for urban China. If the household resides in Guangdong, it is in the top decile of the wealth distributions irrespective of position in the life cycle. However, if the household resides in Liaoning, it belongs to the lowest decile in the wealth distribution with an exception for the household head being aged 41-50 where it is found in the second decile. When the Liaoning household moves up the income distribution it also moves up the wealth distribution. Actually a combination of being positioned in the second-highest decile of the income distribution and

\footnotetext{
${ }^{10}$ When replacing household net worth as dependent variable with the logarithm of household net worth there are no indications of age differences below 60 affecting the dependent variable.

${ }^{11}$ When replacing the dependent variable with $\log$ net worth more coefficients of occupation of household head are estimated with a high t-statistics.
} 
TABLE 4

Regression Analysis of Household Wealth in Urban China (1995)

\begin{tabular}{|c|c|c|c|c|}
\hline \multirow[b]{2}{*}{ Independent Variables } & \multicolumn{2}{|c|}{ Specification I } & \multicolumn{2}{|c|}{ Specification II } \\
\hline & Coefficient & t-value & Coefficient & t-value \\
\hline \multicolumn{5}{|l|}{ Age of household head (years) } \\
\hline$\leq 30$ & $-2,812.71$ & -1.07 & -685.2 & -0.28 \\
\hline $31-40$ & -523.64 & -0.33 & $1,907.1$ & 1.27 \\
\hline \multicolumn{5}{|l|}{$41-50$ (reference) } \\
\hline $51-60$ & $8,166.18$ & 4.67 & $4,838.9$ & 2.91 \\
\hline $61-70$ & -9.60 & 0.00 & 258.2 & 0.13 \\
\hline$>71$ & $-8,344.60$ & -1.89 & $-4,000.5$ & -0.95 \\
\hline Size of household & $4,850.04$ & 6.62 & 778.7 & 1.09 \\
\hline \multicolumn{5}{|l|}{ Occupation of head } \\
\hline Owner or manager of private firm & $7,363.11$ & 1.43 & $5,639.1$ & 1.15 \\
\hline Head of enterprise & $11,954.81$ & 5.49 & $8,618.0$ & 4.16 \\
\hline Professional and technician & $2,708.42$ & 1.39 & 400.6 & 0.22 \\
\hline Office clerk & $2,842.13$ & 1.51 & $2,639.3$ & 1.48 \\
\hline \multicolumn{5}{|l|}{ Skilled worker (reference) } \\
\hline Unskilled worker & 153.22 & 0.08 & $2,386.5$ & 1.31 \\
\hline \multicolumn{5}{|l|}{ Gender of household head } \\
\hline Male & -919.53 & -0.70 & $1,419.2$ & 1.13 \\
\hline \multicolumn{5}{|l|}{ Female (reference) } \\
\hline \multicolumn{5}{|l|}{ Political status of household head } \\
\hline Party member & -449.28 & -0.31 & $-2,463.4$ & -1.81 \\
\hline \multicolumn{5}{|l|}{ Non-party member (reference) } \\
\hline \multicolumn{5}{|l|}{ Education of household head } \\
\hline Primary school or below & $-4,629.72$ & -1.51 & $6,477.4$ & 2.20 \\
\hline Lower-middle school & $-7,337.74$ & -2.96 & -31.7 & -0.01 \\
\hline Upper-middle school or technical school & $-5,175.60$ & -2.25 & 563.4 & 0.26 \\
\hline Professional school & $-2,292.01$ & -0.90 & $1,406.4$ & 0.58 \\
\hline \multicolumn{5}{|l|}{ College or above (reference) } \\
\hline \multicolumn{5}{|l|}{ Province } \\
\hline Beijing & $12,964.04$ & 3.90 & $-7,411.0$ & -2.29 \\
\hline Shanxi & $1,734.99$ & 0.56 & 55.2 & 0.02 \\
\hline Liaoning & $1,858.18$ & 0.60 & $-4,899.1$ & -1.66 \\
\hline Jiangsu & $19,540.56$ & 6.47 & $6,461.6$ & 2.22 \\
\hline Anhui & $1,256.79$ & 0.38 & $-2,843.1$ & -0.91 \\
\hline Henan & $5,508.93$ & 1.73 & $3,826.4$ & 1.27 \\
\hline Hubei & $13,468.17$ & 4.39 & $6,181.1$ & 2.11 \\
\hline Guangdong & $80,460.25$ & 24.78 & $44,351.7$ & 13.23 \\
\hline Sichuan & $5,839.20$ & 1.94 & $-1,172.1$ & -0.41 \\
\hline Yunnan & $12,181.15$ & 3.87 & $5,918.1$ & 1.98 \\
\hline \multicolumn{5}{|l|}{ Gansu (reference) } \\
\hline Household income & & & 2.2 & 27.42 \\
\hline Constant & $11,276.34$ & 2.47 & $-4,642.8$ & -1.06 \\
\hline Adj $R^{2}$ & 0.167 & & 0.249 & \\
\hline Mean of dependent variable (yuan) & 40,251 & & 40,251 & \\
\hline F-value & 52.6 & & 83.1 & \\
\hline No. of observations & 6,932 & & 6,932 & \\
\hline
\end{tabular}

Notes: The dependent variable is household wealth. Analysis units are households. Size of household is measured by the number of household members.

Source: Urban Household Income Survey 1995 by Institute of Economics, CASS. 
TABLE 5

Prediction of Household Wealth in Urban China (1995)

\begin{tabular}{|c|c|c|}
\hline & $\begin{array}{l}\text { Predicted Wealth } \\
\text { (yuan) }\end{array}$ & $\begin{array}{c}\text { Decile in the Wealth } \\
\text { Distribution }\end{array}$ \\
\hline Mean value & 40,251 & 7 \\
\hline \multicolumn{3}{|c|}{ Scenario I (household income set as mean of the second lowest decile) } \\
\hline Age $\leq 30$ and Liaoning & 11,721 & 1 \\
\hline Age $\leq 30$ and Guangdong & 68,188 & 10 \\
\hline Age $41-50$ and Liaoning & 18,009 & 2 \\
\hline Age $41-50$ and Guangdong & 74,476 & 10 \\
\hline Age $>70$ and Liaoning & 8,331 & 1 \\
\hline Age $>70$ and Guangdong & 64,798 & 10 \\
\hline \multicolumn{3}{|c|}{ Scenario II (household income set as mean of the fifth decile) } \\
\hline Age $\leq 30$ and Liaoning & 18,600 & 2 \\
\hline Age $\leq 30$ and Guangdong & 75,068 & 10 \\
\hline Age $41-50$ and Liaoning & 24,888 & 3 \\
\hline Age $41-50$ and Guangdong & 81,356 & 10 \\
\hline Age $>70$ and Liaoning & 15,210 & 1 \\
\hline Age $>70$ and Guangdong & 71,678 & 10 \\
\hline \multicolumn{3}{|c|}{ Scenario III (household income set as mean of the second highest decile) } \\
\hline Age $\leq 30$ and Liaoning & 33,847 & 6 \\
\hline Age $\leq 30$ and Guangdong & 90,314 & 10 \\
\hline Age $41-50$ and Liaoning & 40,135 & 7 \\
\hline Age $41-50$ and Guangdong & 96,602 & 10 \\
\hline Age $>70$ and Liaoning & 30,457 & 5 \\
\hline Age $>70$ and Guangdong & 86,924 & 10 \\
\hline
\end{tabular}

Notes: The predictions are based on estimates reported for Specification II in Table 4. It is assumed that a household is headed by a male, non-party member, upper-middle school graduate who is a skilled worker and has three members.

belonging to the richest part of the life cycle moves the household as high as the seventh decile in the wealth distribution.

We end this section by reflecting on why present income and wealth of a household are closely related in urban China. First, in a rapidly growing economy, one can suppose that income recently earned should be important for buying consumer durables and accumulating financial assets. While this reasoning suggests a causal link between household income and household wealth, there is most probably also an element of the two being jointly determined. In urban China, household income is strongly linked to wages, which in turn are determined at the level of the work unit. The work unit was also central in housing reform, which typically was implemented so that better-paid workers such as officials and managers were allocated housing of higher value than the lower-paid workers received. So the manner in which housing reform was implemented is the second link between household income and household wealth.

\section{A Comparison with Rural China and an Assessment of Wealth INEQUALITY IN CHINA AS A Whole}

We now compare our results for urban China in 1995 with results for rural China for the same year. We also pool the two surveys to arrive at the first 
TABLE 6

Distribution of Household Wealth in Rural China (1995)

\begin{tabular}{lccccc}
\hline \hline & $\begin{array}{c}\text { Mean } \\
\text { (yuan) }\end{array}$ & $\begin{array}{c}\text { Proportion of } \\
\text { Net Worth }\end{array}$ & Gini & $\begin{array}{c}\text { Concentration } \\
\text { Coefficient }\end{array}$ & Contribution \\
\hline Net worth & $45,869.7$ & 100.00 & 0.325 & & 100 \\
Value of land & $21,476.6$ & 46.82 & 0.377 & 0.291 & 41.92 \\
Housing & $14,447.2$ & 31.50 & 0.455 & 0.368 & 35.66 \\
Financial assets & $4,538.9$ & 9.90 & 0.607 & 0.416 & 12.66 \\
Durables & $3,009.9$ & 6.56 & 0.361 & 0.191 & 3.86 \\
Productive assets & $2,665.9$ & 5.81 & 0.632 & 0.333 & 5.95 \\
Debts & -268.9 & -0.59 & 0.951 & -0.027 & -0.05 \\
\hline
\end{tabular}

Source: Rural Household Income Survey 1995 by Institute of Economics, CASS.

estimates ever made, to our knowledge, of wealth inequality for China as a whole. ${ }^{12}$ This makes it possible to compare wealth inequality in China with wealth inequality reported for other countries.

In Table 6 we report results for rural China derived from the Rural Household Survey 1995. ${ }^{13}$ To arrive at these results we have followed Brenner (2001) in imputing the value of user rights to land from the gross value of agricultural output. However, we differ from Brenner (2001) by including the value of durable goods. ${ }^{14}$

Average household net worth in urban China is found to be 14 percent lower than in rural China. ${ }^{15}$ Considerable differences between urban and rural China are found in possession of wealth components. Urban households possess no land and on average fewer production assets than households in rural China. This simply reflects the fact that most rural household members are farmers while the overwhelming proportion of urban dwellers is employed workers. On the other hand, urban households possess on average more than two times the financial assets and three times the durable goods of rural households. The value of housing wealth is 23 percent higher in urban areas than in rural areas. According to our data, debts are on average very small in rural China.

${ }^{12}$ When doing this we use weights based on estimates of the number of rural and urban inhabitants, respectively, in China 1995 as reported by the National Bureau of Statistics. In this way we considered that a rural household in the rural survey and a urban household in the urban survey did not have the same probability to be sampled. However, we did not consider that the urban sample was drawn from a somewhat smaller number of provinces. To do so would have been rather difficult as sample weight taking this into account have not been developed. However, it can be mentioned that when the original sampling design was made, provinces were selected with an aim to capture essential spatial differences. For example, the rural as well as the urban sample consist of provinces in each of the three economic regions of China (East, Central and West).

${ }^{13}$ The rural survey covered 7,998 households with 34,739 persons living in 19 provinces (Beijing, Hebei, Shanxi, Liaoning, Jilin, Jiangsu, Zhejiang, Anhui, Jiangxi, Shandong, Henan, Hubei, Hunan, Guangdong, Sichuan, Guizhou, Yunnan, Shaanxi and Gansu).

${ }^{14}$ This information is taken from answers to the survey, which also included questions of possession of particular goods (number of bicycles, black and white TV, color TV, etc). For the few households that did not provide information on the value of a particular durable, we imputed the value of the good based on information from households that had provided complete responses. (Such a procedure was not used for the similar variables in the urban sample, as the information was more complete in this respect.)

${ }^{15}$ However, as households in urban China have on average fewer members than households in rural China, household net worth per capita in urban China exceeds household net worth per capita in rural China by 22 percent. 
TABLE 7

The Distribution of Wealth in the Entire Country of China in 1995

\begin{tabular}{lccccc}
\hline \hline & $\begin{array}{c}\text { Mean } \\
\text { (yuan) }\end{array}$ & $\begin{array}{c}\text { Proportion of } \\
\text { Net Worth }\end{array}$ & Gini & $\begin{array}{c}\text { Concentration } \\
\text { Coefficient }\end{array}$ & Contribution \\
\hline Net worth & $43,495.3$ & 100.00 & 0.399 & & 100 \\
Housing & $15,401.1$ & 35.41 & 0.632 & 0.531 & 47.09 \\
Value of land & $13,823.8$ & 31.78 & 0.603 & 0.369 & 29.39 \\
Financial assets & $6,853.1$ & 15.76 & 0.639 & 0.357 & 14.07 \\
Durables & $5,159.3$ & 11.86 & 0.481 & 0.132 & 3.92 \\
Production assets & $1,859.7$ & 4.28 & 0.775 & 0.430 & 4.61 \\
Other assets & 626.2 & 1.44 & 0.935 & 0.262 & 0.95 \\
Debts & -228.1 & -0.52 & 0.964 & -0.032 & -0.04 \\
\hline
\end{tabular}

Source: Urban and Rural Household Income Survey 1995 by Institute of Economics, CASS.

An interesting finding reported in Table 6 is that the distribution of wealth in urban China is more unequal than in rural China. This situation is exactly the opposite of how inequality in disposable household income is related, as income inequality is larger in rural China than in urban China. An important background for the even distribution of wealth in rural China is the relatively even distribution of user rights to land, and its concentration coefficient is reported to be 29 percent.

We now turn to the exercise of merging data from the rural and urban samples for 1995 to arrive at the wealth distribution for China as a whole. The results, which are thus the first estimates of the distribution of wealth in China as a whole, are summarized in Table 7. The value of the Gini coefficient for China as a whole is estimated to 39.9 percent, which is between the one for urban and rural China. Housing wealth is the single most important component of net worth in China as a whole, and has the highest concentration coefficient. Almost half of inequality in net worth in China as a whole can be attributed to housing. Land, the second largest component, has a concentration coefficient slightly lower than the Gini coefficent for net worth and its contribution to the Gini for net worth is 29 percent. Durable goods are relatively equally shared among Chinese households and only 4 percent of the Gini for net worth can be attributed to this component.

In Table 8 we report measures of wealth inequality based on household surveys for 11 countries as gathered from various studies by Davies and Shorrocks (2000) and add to it our estimates for urban China, rural China and China as a whole. We present Gini coefficients and the proportion of wealth owned by the wealthiest 5 percent. Without question, there are differences in methods and in definitions among the surveys. ${ }^{16}$ However, we are convinced that such differences do not provide the main reason for the much lower inequality in the distribution of wealth being reported for China as a whole and its urban and rural parts in 1995, than for the other eleven countries. The difference in magnitude for the Gini coefficients and in the proportion owned by the richest 5 percent is simply too large to only be due to differences in methods and definitions.

The USA and China are the extremes in this comparison. While the richest 5 percent of the households in the USA own more than half of total wealth, their

${ }^{16}$ For example, the fact that the two estimates for Sweden differ a great deal is due, to a large extent, to whether the value of durables (relatively equally distributed) is included or not. 
TABLE 8

A Comparison of Inequality in Household Wealth Distribution in Various Countries

\begin{tabular}{lccc}
\hline \hline Country & Year & The Share of Top 5\% & Gini Coefficient $(\%)$ \\
\hline USA & 1983 & 56 & 79 \\
France & 1986 & 43 & 71 \\
(West) Germany & 1988 & & 69 \\
Canada & 1984 & 38 & 69 \\
Australia & 1986 & 41 alternatively & \\
Italy & 1987 & 31 & 60 \\
Korea & 1988 & 32 & 58 \\
Ireland & 1987 & 31 & 52 \\
Japan & 1984 & 29 & 59 \\
Sweden & 1985 & 25 & 40 \\
China as a whole & 1995 & 24 & 50 \\
Urban China & 1995 & 24 & 33 \\
Rural China & 1995 & 21 & \\
\hline
\end{tabular}

Source: Davies and Shorrocks (2000) and Urban and Rural Household Income Survey 1995 by Institute of Economics, CASS.

counterparts in China own about one-fifth of the total wealth in the country. Only Japan with a Gini coefficient of 52 percent in 1984 has an inequality in the distribution of net wealth relatively close to the 40 percent reported for China as a whole. ${ }^{17}$ In international comparisons the distribution of wealth in China in the middle of the 1990s thus proves to be rather equal.

\section{Conclusions}

In this paper we have analyzed the composition, inequality and determinants of wealth in urban China. The results have been compared with the situation in rural China, which previously has been researched. We have also generated the first estimates ever presented of the distribution of household wealth in China as a whole. The analysis was based on household samples covering large parts of China for 1995.

Several findings have emerged. Starting with the composition of average household wealth, we find that housing is the single most important component in urban China and in China as a whole. Most urban Chinese households keep a bank account while debts are unusual among urban Chinese households, a reflection of an under-developed credit market. We also report that location as indicated by province, as well as current income, both strongly affect wealth of urban households. Households in prosperous provinces are rich as are high-income households. Further, we find that the Gini coefficient for net worth in urban China is as high as 49.6 percent.

${ }^{17}$ The Davies and Shorrocks (2000) survey does not include any countries in transition. We are aware of estimates only for the territory of the former German Democratic Republic. They show average wealth in the East in the middle of the 1990s to be only about one-third of the average for the West. However, it is interesting to note that wealth inequality was not lower in the East than in the West. For example Gini coefficients reported for the East in 1993 were 69 percent and 68 percent in 1998 (Stein, 2001, p. 14). 
It is well known that urban households in China on average have considerably higher incomes than rural households. We report that in 1995 did urban and rural households have similar average net worth. Rural households are the sole owners of user rights of land. On the other hand, urban households are richer in financial assets and ownership of durable goods.

The results on inequality in net worth reported for urban China and China as a whole can be examined from various perspectives. Taking the situation in rural China as point of reference, the distribution of net worth in urban China and to some extent also in China as a whole appears to be rather unequal. In addition, we have reported that in urban China, inequality in household wealth is much larger than inequality in household income. However, if we take the situation in industrialized market economies as point of reference, the distribution of net worth in urban China and particularly in China as a whole appears to be remarkably even. An important background factor for the relatively equal distribution of net worth in China as a whole is that a considerable proportion of Chinese wealth consists of user rights to land shared by many rural residents who have few other assets.

\section{REFERENCES}

Brenner, Mark, "Re-examining the Distribution of Wealth in Rural China," in Carl Riskin, Zhao Renwei, and Li Shi (eds), China's Retreat from Equality: Income Distribution and Economic Transformation, M.E. Sharpe, Armonk, NY, 2001.

Davies, James B. and Anthony F. Shorrocks, "The Distribution of Wealth," in Anthony B. Atkinson and Francois Bourguignon (eds), Handbook of Income Distribution, Volume 1, Elsevier, Amsterdam, 606-75, 2000.

Gustafsson, Bjorn and Li Shi, "A More Unequal China? Aspects of Inequality in the Distribution of Equivalent Income," in C. Riskin, R. Zhao, and Li Shi (eds), China's Retreat from Equality. Income Distribution and Economic Transition, M.E. Sharpe, Armonk, NY, 2001.

Huang, Youqin and William A. V. Clark, "Housing Tenure Choice in Transitional Urban China: A Multilevel Analysis," Urban Studies, 39(1), 7-32, 2002.

Knight, John and Lina Song, The Rural-Urban Divide, Economic Disparities and Interactions in China, Oxford University Press, Oxford, 1999.

Lambert, P., The Distribution and Redistribution of Income, 3rd edition, Manchester University Press, Manchester, 2001.

Logan, John R., Yanjie Bian, and Fuqin Bian, "Housing Inequality in Urban China in the 1990s," International Journal of Urban and Regional Research, 1999, 23(1), 7-25, 1999.

McKinley, Terry, "The Distribution of Wealth in Rural China", PhD thesis, University of California, Riverside, 1992.

_ "The Distribution of Wealth in Rural China," in Keith Griffin and Zhao Renwei (eds), The Distribution of Income in China, Macmillan Press, London, 116-34, 1993.

- The Distribution of Wealth in Rural China, M.E. Sharpe, Armonk, NY, 1996.

Meng, Xin, Labour Market Reform in China, Cambridge University Press, Cambridge, 2000.

Pudney, Stephen, "Income and Wealth Inequality and the Life Cycle: A Non-parametric Analysis for China," Journal of Applied Econometrics, 1993, 8(3), 249-76, 1993.

Pyatt, G., C. N. Chen, and J. Fei, "The Distribution of Income by Factor Components," Quarterly Journal of Economics, 95, 451-73, 1980.

Rao, V. M., "Two Decompositions of the Concentration Ratio," Journal of the Royal Statistical Society, 132, 418-25, 1969.

Stein, H., "The Development of Aggregate Private Wealth and its Distribution in Germany since 1970," Paper presented at the 21st Arne Ryde Symposium, "Non-Human Wealth and Capital Accumulation," University of Lund, August 2001.

Wang, Y. P. and A. Murie, "Social and Spatial Implication of Housing Reform in China," International Journal of Urban and Regional Research, 24(2), 398-417, 2000.

Wu, Fulong, "Changes in the Structure of Public Housing Provision in Urban China," Urban Studies, 33(9), 1601-27, 1996. 
Review of Income and Wealth, Series 52, Number 2, June 2006

Zhang, Xingquan, "Privatization and the Chinese Housing Model," International Planning Studies, 5(2), 191-204, 2000.

Zhao, Renwei, Li Shi, and Carl Riskin (eds), Zhongguo jumin shouru fenpei zai yangju (Re-study on Income Distribution of Chinese Households), Publishing House of Chinese Finance and Economy, Beijing, 1999.

Zhu, Jieming, "The Changing Mode of Housing Provision in Transitional China," Urban Affairs Review, 35(4), 502-19, 2000. 